УДК 004.032.6

() Я. В. Зоренко, канд. техн. наук, доц., В. О. Воробей, магістрант, Б. М. Канєвський, магістрант, В. І. Мазурчак, магістрант, КПІ ім. Ігоря Сікорського, Київ, Україна

\title{
ДОСЛІДЖЕННЯ ТЕХНОЛОГІЙ ПІДГОТОВКИ КОНТЕНТУ ДЛЯ ЕЛЕКТРОННИХ ТА МУЛЬТИМЕДІЙНИХ ВИДАНЬ
}

\section{У представленій роботі розглядаються сучасні технології підготовки контенту для вебресурсів та відеороликів, а також розглянуто перспективні напрями розвитку технологій створення електронних мультимедійних видань на прикладі веб-сайтів та відеоконтенту із анімаційними ефектами.}

\section{Ключові слова: алгоритми тестування; анімаційний ефект;} анімація; вебдизайн; вебресурс; електронне видання; контент; мультимедіа; патентний пошук; підготовка контенту; пошукова оптимізація; проморолик; технологічний процес.

\section{Постановка проблеми}

Існують різні підходи щодо підготовки контенту для електронних та мультимедійних видань. Для веб-сайтів контент створюється зазвичай паралельно із процесом створення прототипу сайту, або вже на завершальному етапі веб-дизайну. Для мультимедійної продукції на основі існуючого контенту здійснюється конструювання майбутнього видання. Проте, як для електронних, так і для мультимедійних видань процес підготовки контенту є визначальним.

Кожного дня у світі створюється та поширюється все більше інформації у вигляді безлічі гігабайтів текстового, графічного та мультимедійного контенту [1]. Тому ступінь відповідності застосованого контенту очікуванням користувачів, значною мірою ви- значає якість електронних та мультимедійних видань. Тож процес підготовки контенту можна вважати ключовим у створенні продукту. Складність підготовки контенту полягаєу відсутності шаблонного алгоритму дій, оскільки кожен продукт індивідуальний та виникає необхідність коригувати контент на всьому етапі його підготовки. Тому важливо визначити головні фактори процесу підготовки контенту.

Отже, дослідження сучасного стану технологій підготовки контенту є актуальним з точки зору пошуку раціональних підходів до підвищення якості електронних та мультимедійних видань.

\section{Аналіз попередніх досліджень}

Сучасні методи оцінювання рівня підготовки контенту для елек- 
тронних видань, зокрема вебсайтів, побудовані на застосуванні спеціальних метрик для визначення доцільності застосування різноманітного контенту [2]. Для електронних видань можна виділити методи вимірювання доцільності контенту за чотирма ознаками: базові метрики, метрики залучення, SEO-метрики, бізнес-метрики (рис. 1). Показники базових метрик можна відстежувати за допомогою онлайн сервісів «Google Analytics», «Webometrics», «Clicky», «Piwik», «Openwebanalytics» тощо.

Ще одним із важливих етапів створення веб-сайту, на якому також оцінюється застосований контент та його вплив на функціональність електронного видання є процес тестування. Саме на цьому етапі перевіряється наявність помилок при візуальному оформленні та функціональність веб-сайту в цілому, здійснюється пошук та виправлення дефектів. Тому тестування вебсайтів $є$ процесом перевірки відповідності між його реальною та очікуваною роботою і включає: діяльність 3 планування робіт (Test Management), проектування тестів (Test Design), виконання тестування (Test Execution) та аналізу отриманих результатів (Test Analysis) [3-5].

Загалом типові засоби тестування веб-сайтів розрізняють за видами: функціональне, безпекове, за зручністю користування, продуктивності, сумісності та бета-тестування [3-5]. Для кожного виду тестування можна знайти сучасний засіб реалізації, що відображено в узагальненій схемі програмних засобів тестування веб-сайтів (рис. 2).
Щодо мультимедійних видань, то найбільш популярним видом контенту $є$ різноманітна відеоінформація, зокрема короткі відеоролики, що можуть бути використані як основа майбутнього мультимедійного видання, або бути самостійним цифровим продуктом. Із розвитком цифрових технологій відеоролики стали доволі ефективною формою донесення інформації в соціальних мережах та відео-платформах. Крім того в більшості відеороликів використовується 3D-анімація. Однак при підготовці контенту для створення мультимедійних видань (рис. 3) слід враховувати складність їх виробництва, що спричинено потребою у раціональному поєднанні аудіо-, відео- і текстової інформації, а також доцільності створення ефектів анімації. Зокрема додавання ефектів анімації до складових контенту, які використовуються при створенні мультимедійного видання, здатні значно підвищити рівень якості видання в цілому [6-10].

Згідно аналізу поширених програмних засобів та анімаційних ефектів [11], що застосовуються в рекламних відеороликах можна скласти класифікацію основних анімаційних ефектів на прикладі програмного продуктy Adobe After Effects (рис. 4).

Слід відзначити, що для різних видів інформації (текстова, графічна, відео, аудіо та ін.), що застосовується у вигляді контенту для електронних та мультимедійних видань, і показники, і методи оцінки, і способи підбору інформації дещо відрізнятися. В цілому контент для електрон- 


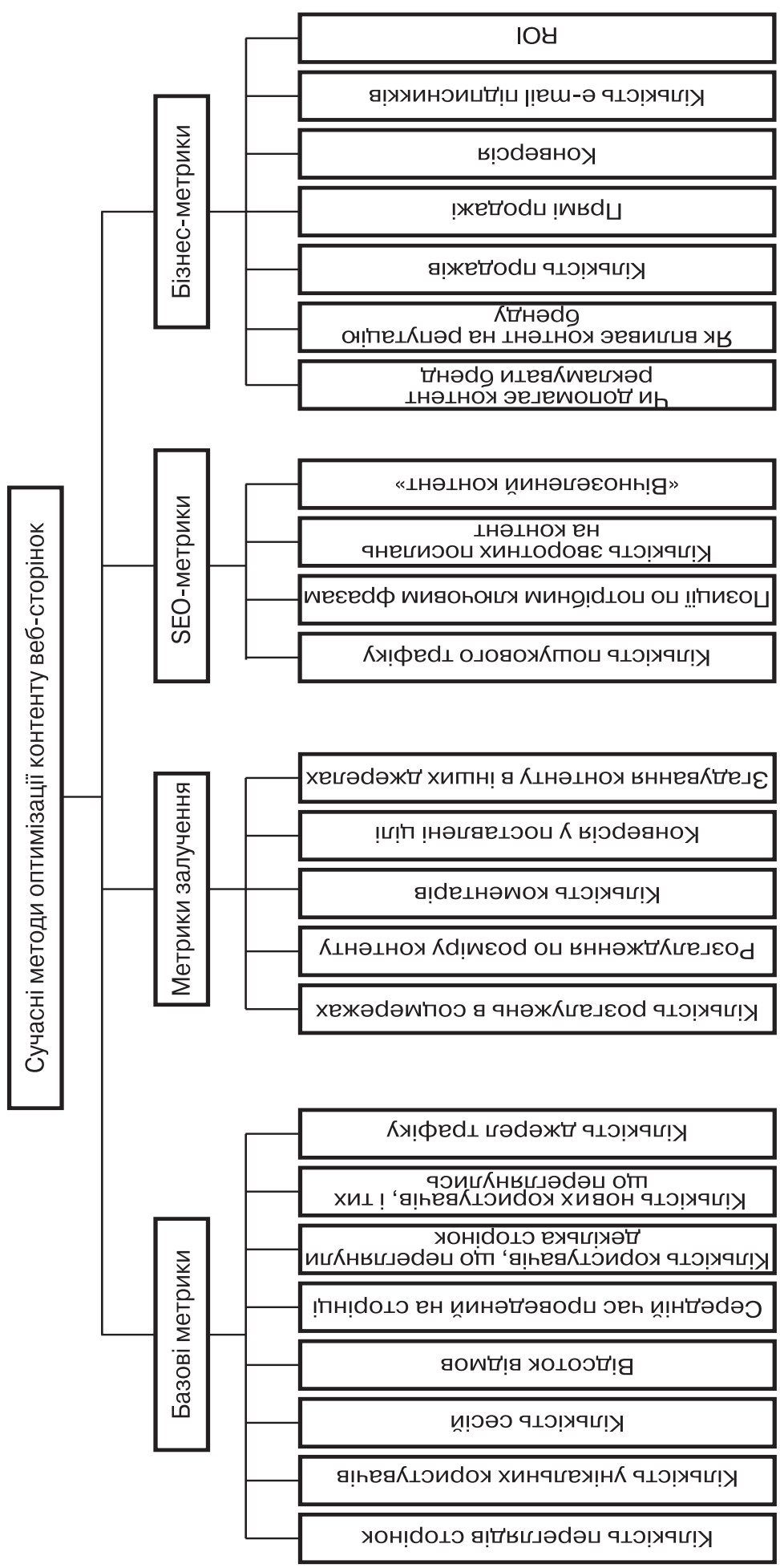




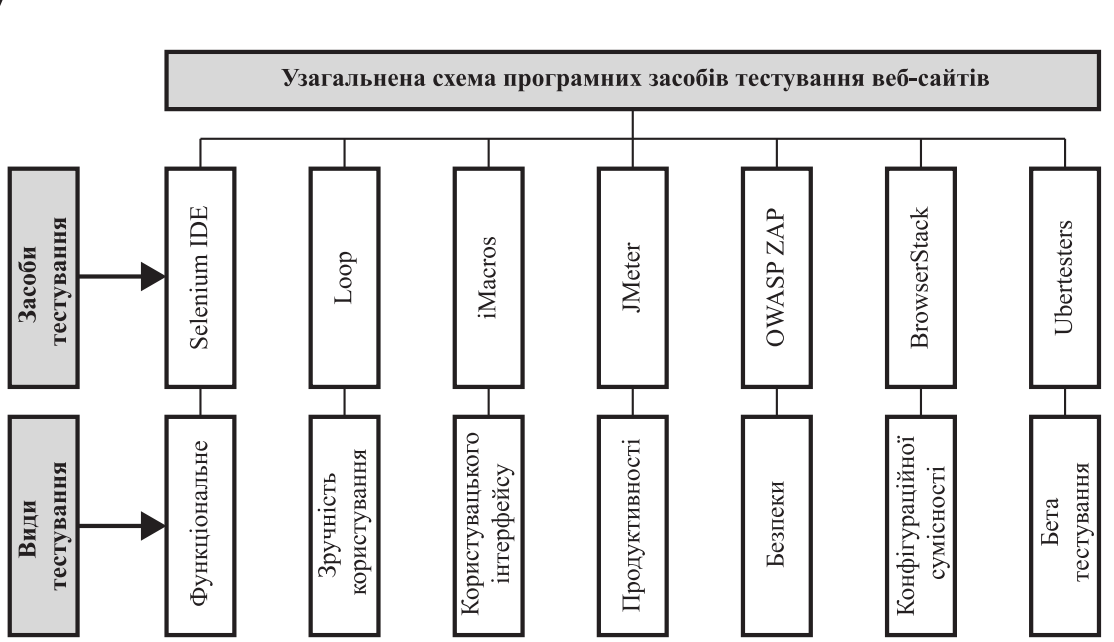

Рис. 2. Узагальнена схема програмних засобів тестування веб-сайтів

них та мультимедійних видань можна класифікувати за різними ознаками [12-17].

Отже, при процес підготовки контенту для електронних та мультимедійних видань є доволі важливим та вимагає врахування особливостей майбутнього видання, його цільової аудиторії, раціонального підбору інформації, застосування різних методів попереднього оцінювання і тестування щодо впливу на якість майбутнього видання. Тому до- слідження процесів підготовки контенту для електронних та мультимедійних видань $є$ актуальним та на часі.

\section{Мета роботи}

Визначення сучасного стану технологій підготовки контенту для електронних та мультимедійних видань, а також встановлення перспективних напрямків щодо підвищення якості контенту та конкурентоздатності створюваних видань.

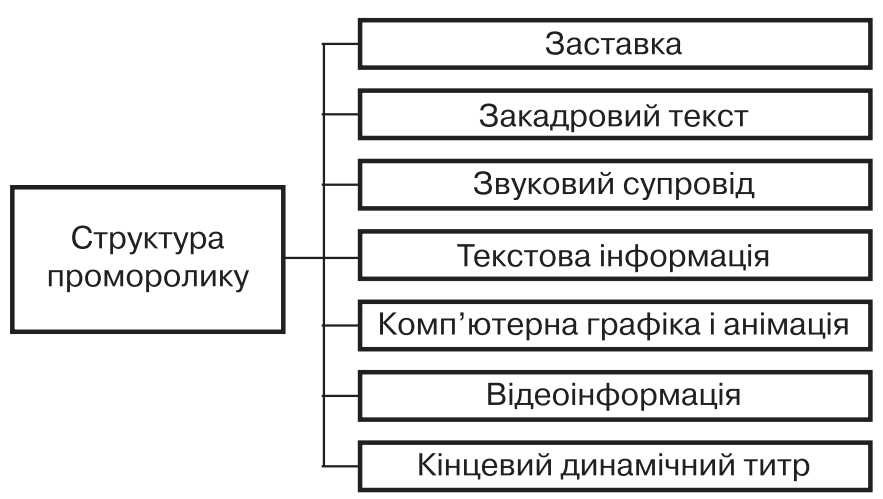

Рис. 3. Складові майбутнього контенту для мультимедійного видання на прикладі проморолику 

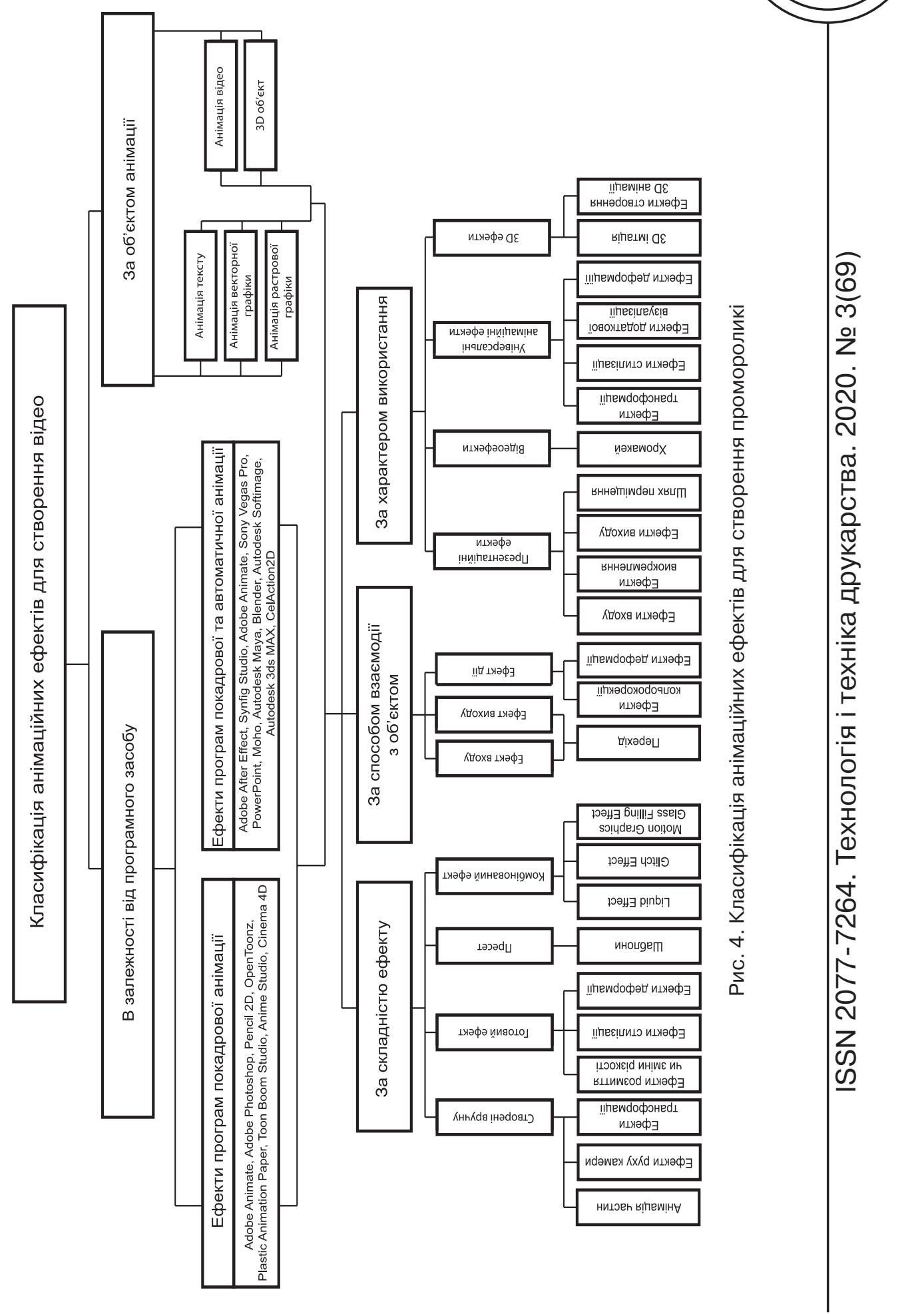


\section{Результати проведених досліджень}

Для встановлення перспективи розвитку технологій створення та підготовки контенту для електронних та мультимедійних видань було проведено патентний пошук із глибиною 11 років. В результаті проведених досліджень було проаналізовано понад 4000 патентів та відібрано біля 1500 патентів за такими інтернет-ресурсами: Укрпатент, Espacenet, Google Patents (табл.).

На основі результатів проведеного патентного пошуку за темою дослідження було побудовано кумулятивні криві видачі патентів за різними напрямками технологій підготовки контенту для електронних та мультимедійних видань (рис. 6-11).

Аналіз кумулятивної кривої видачі патентів (рис. 6) у період з 2009 по 2020 роки за технологіями підготовки контенту для електронних видань виявив стале зростання кількості виданих патентів, що доводить актуальність технологій підготовки контенту для електронних видань.

Якщо розглядати динаміку видачі патентів за окремими напрямками технологіями підготовки контенту для електронних видань (рис. 7) можна відзначити, що такі напрямки, як процеси підготовки контенту, методики визначення впливу контенту на цифровий ресурс та методики аналізу контенту мають тенденцію до сталого, але не значного зростання. Однак, такі напрями, як процеси створення контенту, застосуванню контент-маркетингу та методики SEO-оптимізації, або пошукової оптимізації сайту (від англ. Search Engine Optimization), навпаки, мають тенденцію до значного зростання. Особливо, велика тенденція до зростання кількості патентів спостерігається після 2015 року.

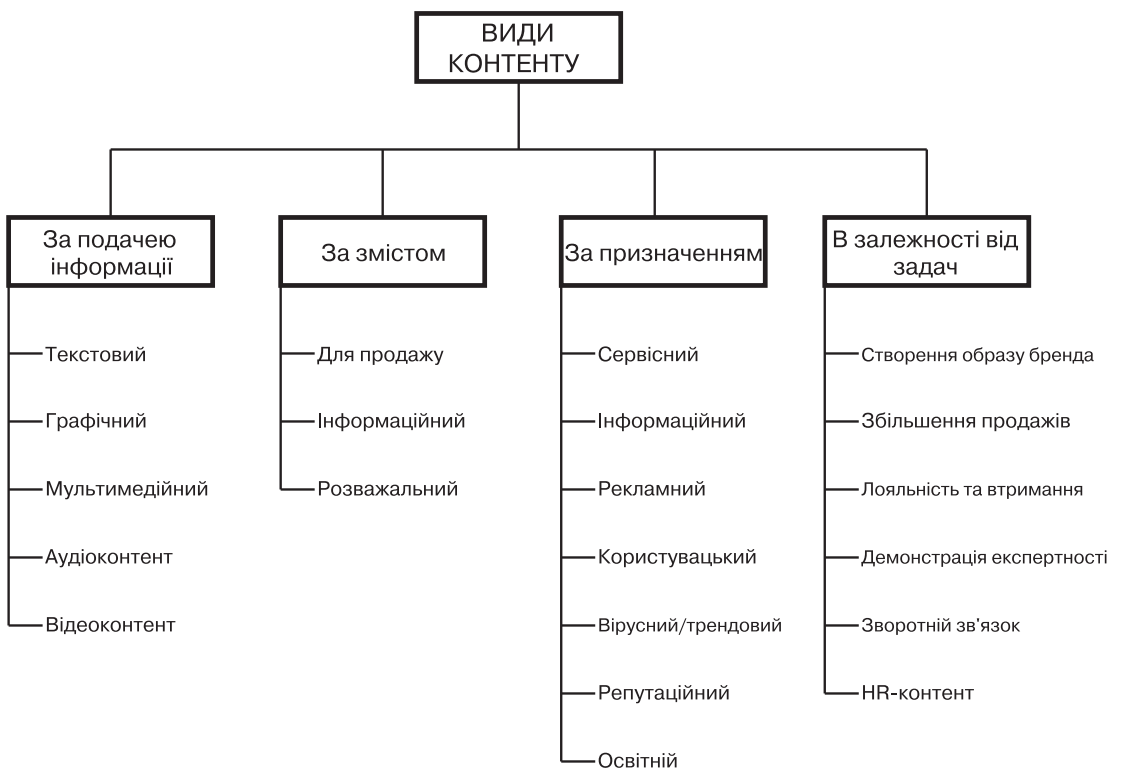

Рис. 5. Класифікація контенту за різними ознаками 
Розподіл патентів за країнами (рис. 8) вказує на значну кількість патентів за напрямком виданих в Китаї та США. Отже, у світі спостерігається інтерес до створення та підготовки якісного контенту для залучення більшої аудиторії користувачів електронних видань.

Побудована на основі результатів патентного пошуку кумулятивна крива видачі патентів у період з 2009 по 2019 роки за технологіями розробки і тестуван- ня електронних видань (рис. 9), виявила сталу динаміку розвитку технологій пов'язаних зі створенням і тестування електронних видань, що пояснюється сталим інтересом дослідників до процесу створення веб-сайтів.

Більш детальний аналіз патентної інформації за напрямами розвитку технологій розробки і тестування електронних видань (рис. 10), виявив значну зацікавленість у програмному забезпеченні для розроблення та тесту-

Регламент патентного пошуку

\begin{tabular}{|c|c|c|c|c|c|}
\hline Предмет пошуку & Мета & Країни & $\begin{array}{c}\text { Класифі- } \\
\text { каційні } \\
\text { індекси }\end{array}$ & $\begin{array}{c}\text { Ретро- } \\
\text { спектив- } \\
\text { ність }\end{array}$ & $\begin{array}{c}\text { Джерела } \\
\text { інформації }\end{array}$ \\
\hline $\begin{array}{l}\text { 1.1. Процеси підготов- } \\
\text { ки контенту. } \\
\text { 1.2. Контент. } \\
\text { 1.3. Вплив контенту } \\
\text { на цифровий ресурс. } \\
\text { 1.4. Контент-марке- } \\
\text { тинг. } \\
\text { 1.5. Аналіз контенту. } \\
\text { 1.6. АЕО-оптимізація. } \\
\text { 2.1. Структура сайту. } \\
\text { 2.2. Програмне забез- } \\
\text { печення розроблення } \\
\text { та тестування веб- } \\
\text { сайтів. } \\
\text { 2.3. Режими і параме- } \\
\text { три тестування. } \\
\text { 2.4. Апаратно-про- } \\
\text { грамне забезпечення } \\
\text { робочих станцій студії } \\
\text { розроблення веб- } \\
\text { сайтів. } \\
\text { 2.5. Технології та ме- } \\
\text { тоди створення і тес- } \\
\text { тування веб-сайтів. } \\
\text { 3.1. Проморолик } \\
\text { 3.2. Технології } \\
\text { комп'ютерної анімації } \\
\text { 3.3. Анімаційні ефекти } \\
\text { 3.4. Програмне забез- } \\
\text { печення комп'ютерної } \\
\text { анімації } \\
\text { 3.5. Параметри оцінки } \\
\text { анімації }\end{array}$ & $\begin{array}{l}\text { Визначення } \\
\text { тенденцій } \\
\text { розвитку } \\
\text { процесів } \\
\text { підготовки } \\
\text { контенту } \\
\text { для елек- } \\
\text { тронних } \\
\text { мультиме- } \\
\text { дійних } \\
\text { видань }\end{array}$ & $\begin{array}{l}\text { США, } \\
\text { Китай, } \\
\text { Японія, } \\
\text { Південна } \\
\text { Корея, } \\
\text { Німеччина, } \\
\text { Франція, } \\
\text { Австралія, } \\
\text { Україна }\end{array}$ & $\begin{array}{l}\text { G06F9, } \\
\text { G06F15, } \\
\text { G06F16, } \\
\text { G06F17, } \\
\text { G06F30, } \\
\text { G06K9, } \\
\text { G06T11, } \\
\text { G06T13, } \\
\text { G06Q10, } \\
\text { G06Q30, } \\
\text { G11B2, } \\
\text { H04N19, } \\
\text { H04N21, } \\
\text { H04L29, } \\
\text { H04L67, } \\
\text { H04L65 }\end{array}$ & $\begin{array}{l}11 \text { років } \\
\text { (2009- } \\
2020 \\
\text { pp.) }\end{array}$ & $\begin{array}{l}\text { Тнтернет ре- } \\
\text { сурси: } \\
\text { ер.espacenet. } \\
\text { com, Google } \\
\text { Patents, } \\
\text { Укрпатент } \\
\text { (https://library. } \\
\text { uipv.org), } \\
\text { Pocпатент } \\
\text { (http://www1. } \\
\text { fips.ru/wps/ } \\
\text { portal) }\end{array}$ \\
\hline
\end{tabular}




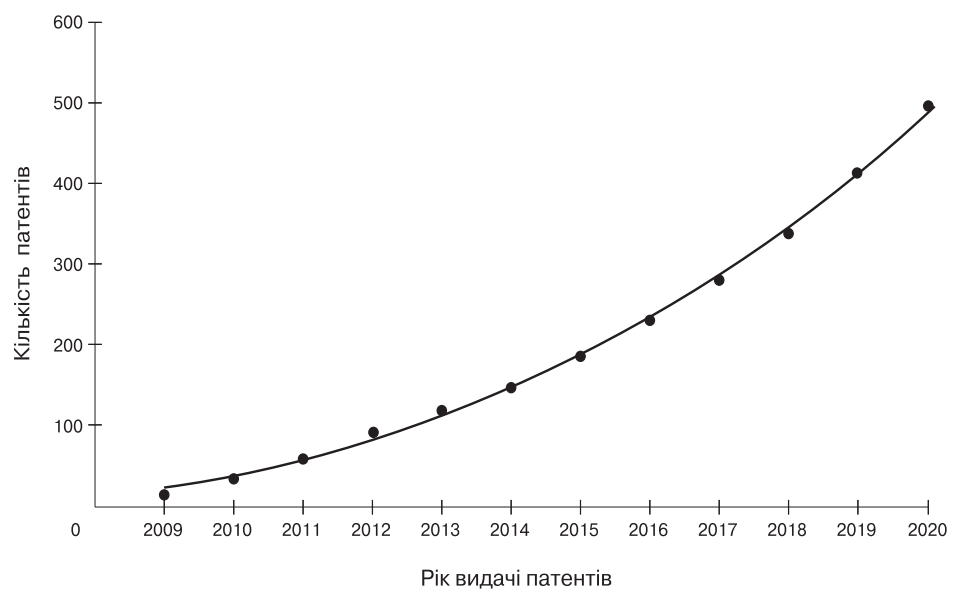

Рис. 6. Кумулятивна крива із динамікою видачі патентів у період з 2009 по 2020 роки за технологіями підготовки контенту для електронних видань

вання веб-сайтів, а також вдосконаленню структури веб-сайту, що покликані збільшити функціональність та якість веб-сайту. Менша динаміка патентування спостерігається за напрямком вдосконалення режимів і параметрів процесу тестування веб-сайту.
Розподіл патентів за країнами для технологій розробки і тестування електронних видань вказує на значну кількість патентів виданих в США, Тайвані, Японії та Мексиці.

Згідно аналізу патентної інформації за останні 11 років за

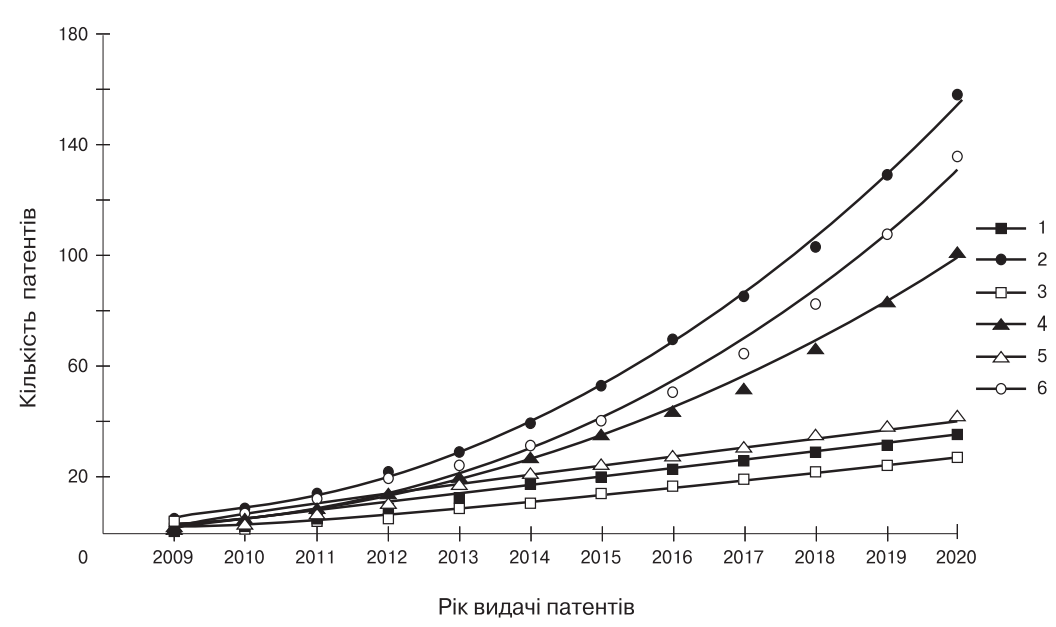

Рис. 7. Кумулятивна крива із динамікою видачі патентів за окремими напрямами за технологіями підготовки контенту для електронних видань:

1 - процеси підготовки контенту; 2 - контент; 3 - вплив контенту на цифровий ресурс; 4 - контент-маркетинг; 5 - аналіз контенту; 
технологіями створення мультимедійних видань, на прикладі відео роликів із анімаційними ефектами, можна констатувати значну популяризацію даної технології після 2017 року (рис. 11).

Аналізуючи тенденцію кількості виданих патентів за 11 років (рис. 12) за різними напрямами технологій створення промороликів із анімаційними ефектами, можна відмітити різку популяризацію технологій комп'ютерної анімації та анімаційних ефектів, що застосовуються для створення контенту для мультимедійних видань.

Також, на основі проведеного аналітичного та патентного пошуку було розроблено алгоритм методики вибору раціональних параметрів підготовки контенту для вебресурсів. Основними етапами, даного алгоритму є визначення основної мети застосування контенту, аналіз

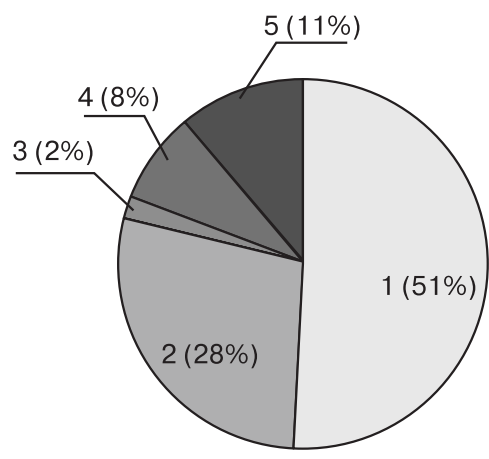

Рис. 8. Діаграма розподілу виданих патентів за країнами: 1 - Китай; 2 - США; 3 - Південна Корея; 4 - Японія; 5 - Інші країни

доступних даних та їх обробка, формування вхідної інформації, підбір команди, адаптація, пошукова оптимізація, вимірювання ефективності для визначення пріоритетних параметрів тощо (рис. 13).

Запропонований алгоритм методики вибору раціональних

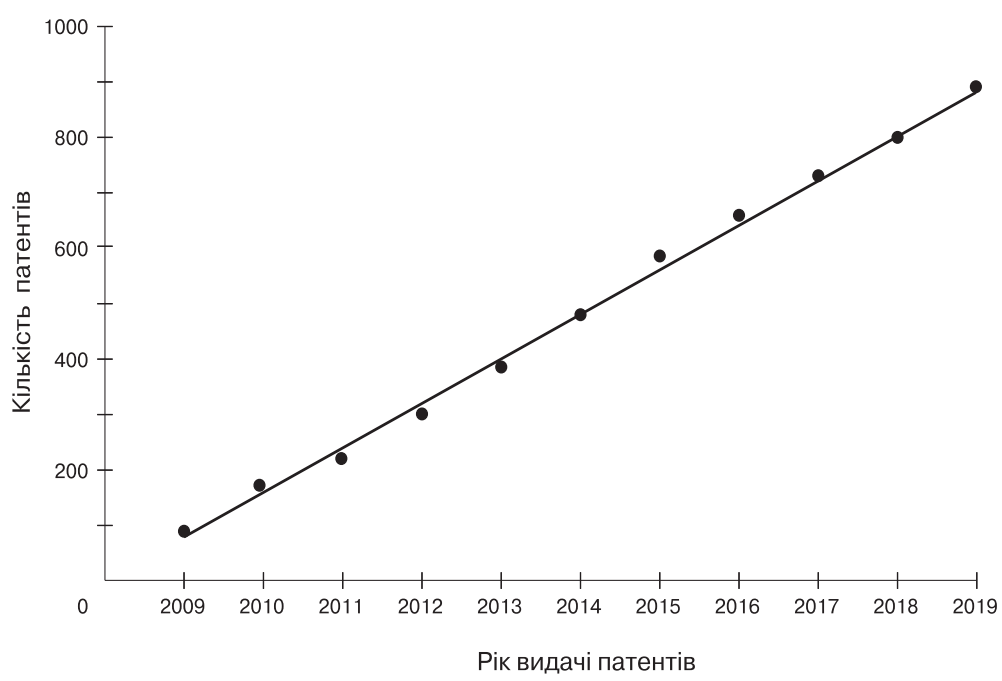

Рис. 9. Кумулятивна крива із динамікою видачі патентів у період з 2009 по 2019 роки за технологіями розробки і тестування електронних видань 


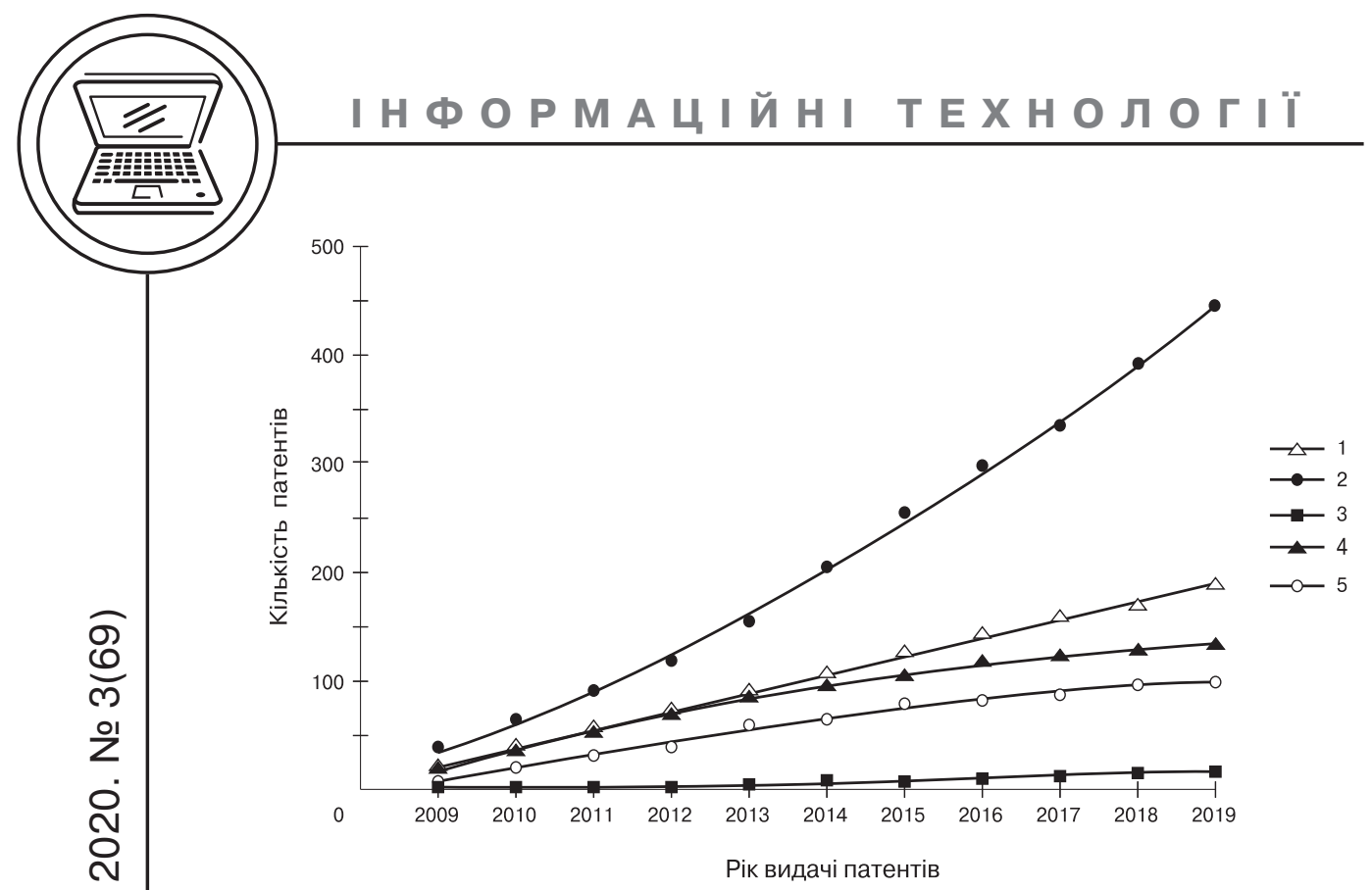

Рис. 10. Кумулятивна крива патентів за окремими напрямками: 1 - структура сайту; 2 - програмне забезпечення розроблення та тестування веб-сайтів; 3 - режими і параметри тестування; 4 - апаратно-програмне забезпечення робочих станцій студії розроблення веб-сайтів; 5 - технології та методи створення і тестування веб-сайтів

параметрів підготовки контенту для вебресурсів (рис. 13) відображає етапи підготовки контенту та дозволяє нормалізувати виробничий процес створення вебресурсів. Також розроблений алгоритм дозволяє одержувати прогнозовані результати

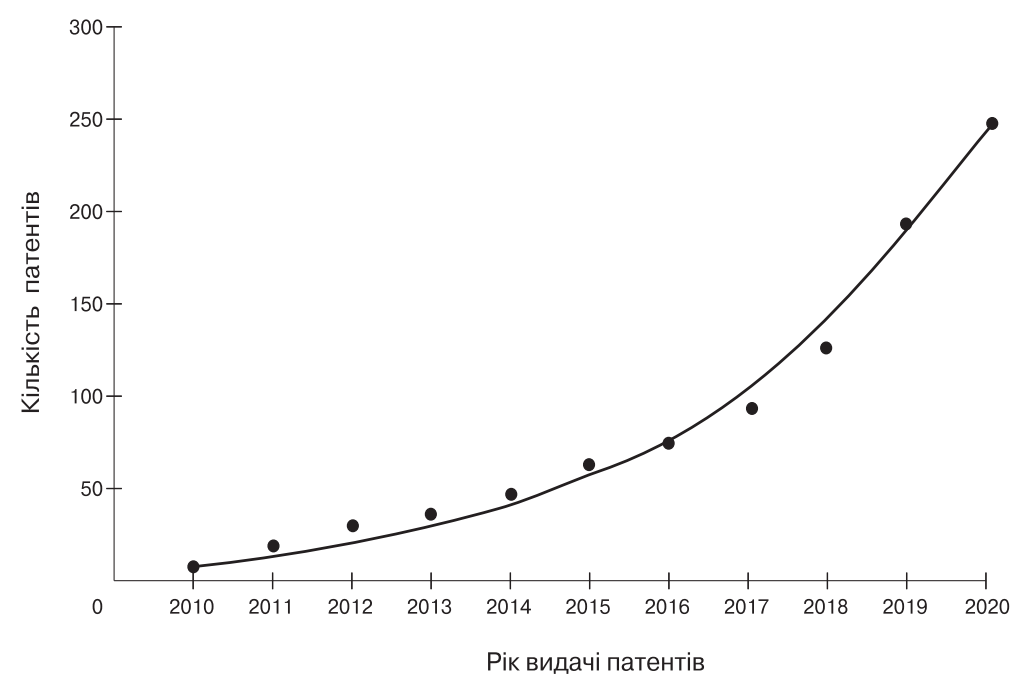

Рис. 11. Кумулятивна крива із динамікою видачі патентів у період з 2009 по 2020 роки за технологіями створення мультимедійних видань 


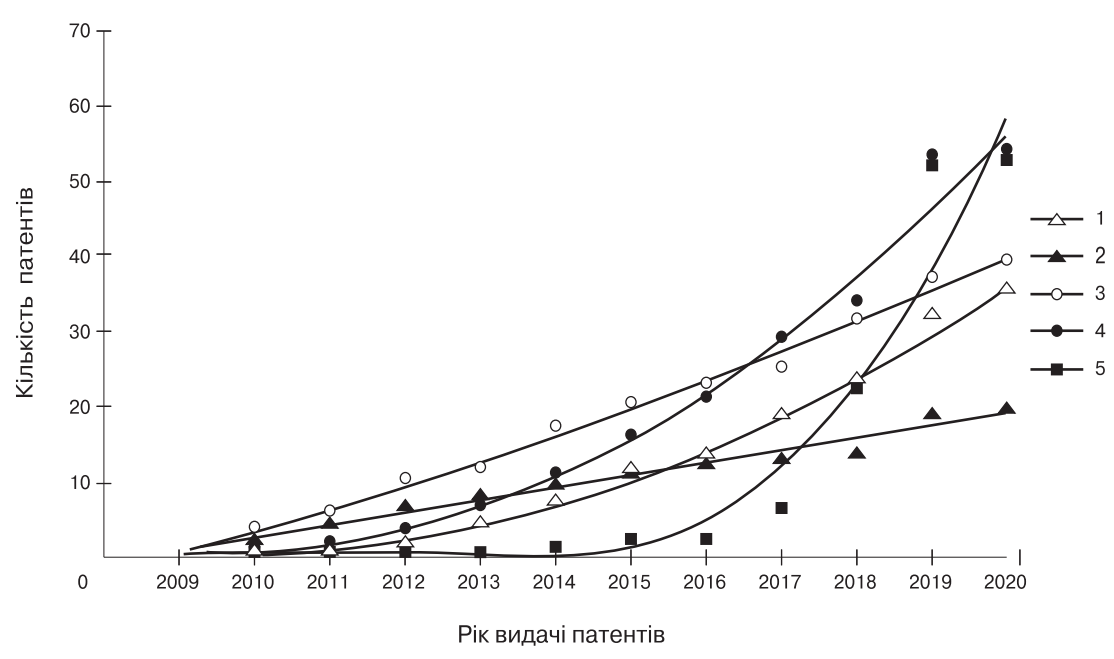

Рис. 12. Кумулятивна крива кількості патентів за напрямками: 1 - програмні засоби анімації; 2 - параметри анімації; 3 - проморолик; 4 - комп'ютерна анімація; 5 - анімаційні ефекти

щодо рівня пошукової оптимізації веб-сайту та підвищення його конкурентноздатності.

Загалом можна виокремити деякі рекомендації при підготовці контенту для вебресурсів: визначення основного завдання та цілей контенту дозволить визначити основні напрямки подальшого розвитку вебресурсу, на якому розміщено контент, аналіз цільової аудиторії дозволить виокремити тематику унікального контенту для збільшення кількості користувачів, проведення моніторингу конкурентів дозволить створити ефективну стратегію підготовки та просування вебресурсу, залучення професійних фахівців та сучасного апаратно-програмного забезпечення збільшить ефективність і зменшить трудомісткість процесу підготовки контенту, постійне поновлення та здійснення пошукової оптимізації контенту підвищує ефективність функціонування веб-сайту у сфері маркетингу тощо.

\section{Висновки}

1. На основі результатів патентного пошуку із ретроспективою 11 років за період 20092020 рp. та з розглядом понад 2000 патентів, було встановлено зростання популярності щодо розвитку технологій підготовки контенту електронних та мультимедійних видань. Причому зростання динаміки патентування спостерігається в цілому після 2017 року, що також доводить перспективність розвитку технологій підготовки контенту.

2. Результати аналізу відібраних патентів виявив значну перспективу розвитку окремих напрямів технологій підготовки контенту для електронних та мультимедійних видань, зокрема за напрямами: процеси створення контенту, методи контент- 
маркетингу та SEO-оптимізації, засоби розроблення та тестування веб-сайтів, методи вдосконалення структури веб-сайту, технології комп'ютерної анімації та методи створення анімаційних ефектів для мультимедійних видань.

3. Серед країн, де було видано найбільшу кількість патентів за технологіями підготовки контенту для електронних та мультимедійних видань були США,
Китай та Японія. Причому більше половини від усього обсягу було видано в Китаї.

4. На основі аналізу фахової вітчизняної та зарубіжної літератури, а також патентної інформації було розроблено алгоритм методики вибору раціональних параметрів підготовки контенту для вебресурсів. Основними етапами якого є: визначення основної мети застосування контенту,
A

B

C

D

$E$

$\mathrm{F}$

G

$\mathrm{H}$

$J$

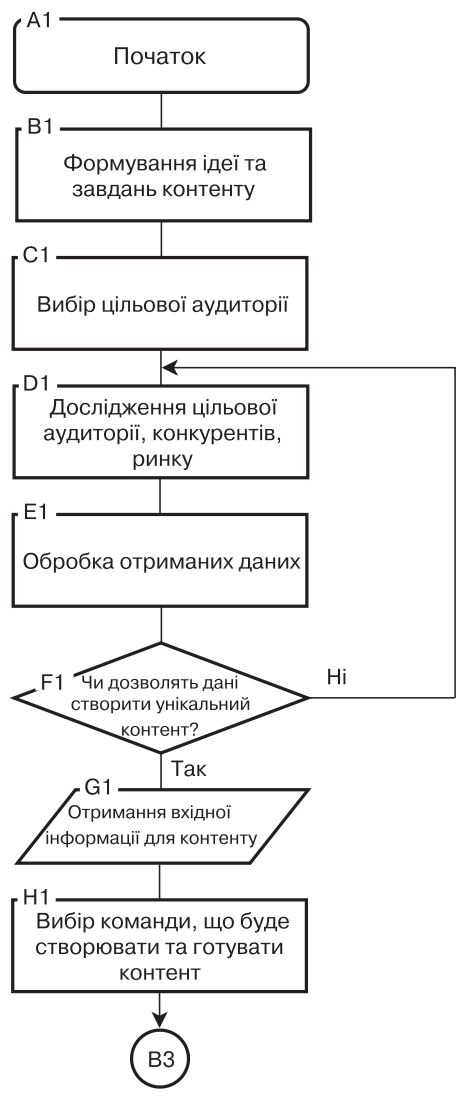

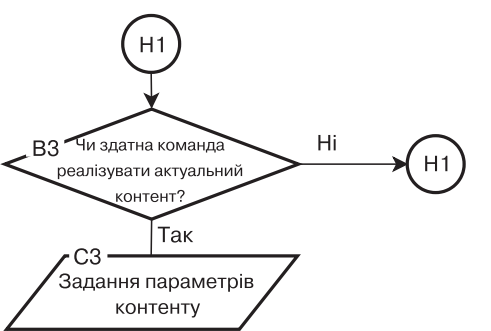

D3 Створення та підготовка контенту у спеціальному ПЗ

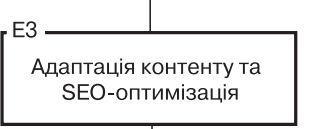

$\left[\begin{array}{l}\mathrm{F} 3 \\ \text { Дослідження ефективності }\end{array}\right.$ контенту

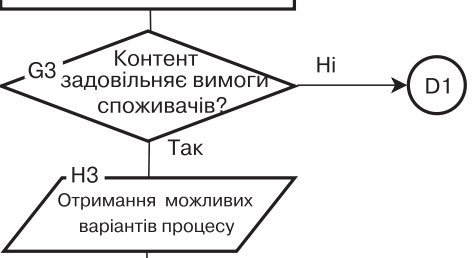
Визначення необхідного
переліку параметрів підготовки контенту для вебресурсів

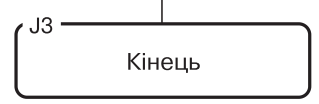

Рис. 13. Алгоритм методики вибору раціональних параметрів підготовки контенту для вебресурсів 
аналіз доступних даних та їх обробка, формування вхідної інформації, підбір команди, адаптація та пошукова оптимізація вебресурсу.
5. Також, на основі проведеного аналітичного дослідження було запропоновано рекомендації для удосконалення процесу підготовки контенту вебресурсів.

\section{Список використаної літератури}

1. Marr B. How much data do we create every day? The mind-blowing stats everyone should read / B. Marr // Forbes. 2018. March 21. [Електронний ресурс]. Режим доступу: https://www.forbes.com/sites/bernardmarr/2018/05/ 21/how-much-data-do-we-create-every-day-the-mind-blowing-stats-everyone-should-read/?sh=309fc2c760ba.

2. Воробей В. Систематизація метрик вимірювання контенту веб-сторінок / В. Воробей // 20-а Міжнародна науково-технічна конференція студентів та аспірантів «Друкарство молоде». 2020. С. 68-71. [Електронний ресурс]. Режим доступу: http://dm-conf.vpi.kpi.ua/2020/paper/view/19774.

3. Мазурчак В. Сучасні засоби тестування веб-сайтів / В. Мазурчак // 20-а Міжнародна науково-технічна конференція студентів та аспірантів «Друкарство молоде». 2020. С. 64-67. [Електронний ресурс]. Режим доступу: http://dm-conf.vpi.kpi.ua/2020/paper/view/19762.

4. Сеник А. П. Створення системи тестування веб-сайтів / А. П. Сеник, А. Я. Сайчук. [Електронний ресурс]. Режим доступу: https://ena.lp.edu.ua:8080/ bitstream/ntb/29065/1/012 032 034.pdf.

5. Тестирование сайта: техники, чек-листы, инструменты. [Електронний ресурс]. Режим доступу: https://geteasyqa.com/ru/qa/test-website/\#an-5.

6. І. Логінов. Класифікація програмного забезпечення для створення анімаційних ефектів в електронних виданнях / І. Логінов // 16-а Міжнародна науково-технічна конференція студентів та аспірантів «Друкарство молоде». 2016. С. 74-76.

7. Effect List for After Effects. [Електронний ресурс]. Режим доступу: http://helpx.adobe.com/ua/after-effects/user-guide.html/ua/aftereffects/using/effect-list.ug.html.

8. Leirpoll J. Motion Graphics Inside Premiere Pro / J. Leirpoll, D. Osborn, P. Murphy, A. Edwards. [Електронний ресурс]. Режим доступу: http://doi.org/ 10.1007/978-1-4842-2890-6_7.

9. Fridsma, L. Adobe After Effects CC Classroom in a Book (2018 release) / L. Fridsma, B. Gyncild. Indianapolis: Adobe Press, 2017. 416 p.

10. І. Єфіменко. Фактори, що впливають на якість анімації у мультимедійних виданнях / І. Єфіменко // 17-а Міжнародна науково-технічна конференція студентів та аспірантів «Друкарство молоде». 2017. С. 94-95.

11. Канєвський Б. Класифікація анімаційних ефектів для відео / Б. Канєвський // XX Міжнародна науково-технічна конференція студентів та аспірантів «Друкарство молоде». 2020. С. 53-56. [Електронний ресурс]. Режим доступу: http://dm-conf.vpi.kpi.ua/2020/paper/view/19727.

12. D. Agarwal. Online Models for Content Optimization. Advances in Neural Information Processing Systems 21 / D. Agarwal, B.-C. Chen, P. Elango, N. Motgi, S.-T. Park, R. Ramakrishnan, S. Roy, J. Zachariah. 2007. [Електронний ресурс]. Режим доступу: https://dl.acm.org/doi/10.1145/2851581.2892359. 
13. Gozhyj A. Uniform Method of Operative Content Management in Web Systems / A. Gozhyj, L. Chyrun, A. Kowalska-Styczen, O. Lozynska // COLINS. 2018. pp. 62-77. [Електронний ресурс]. Режим доступу: https://ceurws.org/Vol-2136/10000062.pdf.

14. Lytvyn V. Content Formation Method in the Web Systems / V. Lytvyn, D. Dosyn, M. Emmerich, I. Yevseyeva // COLINS. 2018. pp. 42-61. [Електронний ресурс]. Режим доступу: https://ceur-ws.org/Vol-2136/10000042.pdf.

15. Воробей В. Сучасні технології створення анімації для електронних видань у форматі ерub / В. Воробей // 19-а Міжнародна науково-технічна конференція студентів та аспірантів «Друкарство молоде». 2019. С. 78-81. [Електронний ресурс]. Режим доступу: http://dm-conf.vpi.kpi.ua/2019/ paper/view/15722.

16. Ілляшенко H. C. SEO-оптимізація як сучасний інструмент інтернетмаркетингу / Н. С. Ілляшенко, О. С. Савченко // Маркетинг і менеджмент інновацій. 2012. № 3. С. 63-74.

17. Кокарєва К. Сучасні тенденції у побудові структури інтерфейсу мультимедійного продукту / К. Кокарєва, Т. Розум // Сучасне репродукування: інжиніринг, моделювання, мульти- та кросмедійні технології: матеріали науково-практичного семінару (23 жовтня 2019 року). Київ: КП ім. Ігоря Сікорського, 2019. С. 66-71. [Електронний ресурс]. Режим доступу: http://ela.kpi.ua/bitstream/123456789/32030/1/Kokareva Rozum 6671.pdf.

\section{References}

1. Marr, B. (2018). How much data do we create every day? The mind-blowing stats everyone should read. Journal of Forbes. Retrieved from https://www. forbes.com/sites/bernardmarr/2018/05/21/how-much-data-do-we-createevery-day-the-mind-blowing-stats-everyone-should-read/?sh=309fc2c760ba [in English].

2. Vorobei, V. (2020). Systematyzatsiia metryk vymiriuvannia kontentu vebstorinok [Systematization of Metrics for Measuring Content of Web Pages]. Journal of 20-a Mizhnarodna naukovo-tekhnichna konferentsiia studentiv ta aspirantiv 'Drukarstvo molode', 68-71. Retrieved from http://dm-conf.vpi. kpi.ua/2020/paper/view/19774 [in Ukrainian].

3. Mazurchak, V. (2020). Suchasni zasoby testuvannia veb-saitiv [Modern Web Site Testing Tools]. Journal of 20-a Mizhnarodna naukovo-tekhnichna konferentsiia studentiv ta aspirantiv 'Drukarstvo molode', 64-67. Retrieved from http://dm-conf.vpi.kpi.ua/2020/paper/view/19762 [in Ukrainian].

4. Senyk, A. P. \& Saichuk, A. Ya. Stvorennia systemy testuvannia veb-saitiv [Creating a Website Testing System]. Retrieved from https://ena.Ip.edu.ua:8080/ bitstream/ntb/29065/1/012 032 034.pdf [in Ukrainian].

5. Testirovanie sayta: tekhniki, chek-listy, instrumenty [Website Testing: Techniques, Checklists, Tools]. Retrieved from https://geteasyqa.com/ru/ qa/test-website/\#an-5 [in Russian].

6. Lohinov, I. (2016). Klasyfikatsiia prohramnoho zabezpechennia dlia stvorennia animatsiinykh efektiv $v$ elektronnykh vydanniakh [Classification of Software for Creating Animation Effects in Electronic Publications]. Journal of 16-a Mizhnarodna naukovo-tekhnichna konferentsiia studentiv ta aspirantiv 'Drukarstvo molode', 74-76 [in Ukrainian]. 
7. Effect List for After Effects. Retrieved from http://helpx.adobe.com/ ua/after-effects/user-guide.html/ua/after-effects/using/effect-list.ug.html [in English].

8. Leirpoll, J. \& Osborn, D. \& Murphy, P. \& Edwards, A. Motion Graphics Inside Premiere Pro. Retrieved from http://doi.org/10.1007/978-1-4842-28906_7 [in English].

9. Fridsma, L. \& Gyncild, B. (2017). Adobe After Effects CC Classroom in a Book (2018 release). Indianapolis: Adobe Press, 416 p. [in English].

10. Yefimenko, I. (2017). Faktory, shcho vplyvaiut na yakist animatsii u multymediinykh vydanniakh [Factors Influencing on the Quality of Animation in Multimedia Editions]. Journal of 17-a Mizhnarodna naukovo-tekhnichna konferentsiia studentiv ta aspirantiv 'Drukarstvo molode', 94-95 [in Ukrainian].

11. Kanievskyi, B. (2020). Klasyfikatsiia animatsiinykh efektiv dlia video [Classification of Animation Effects for Video]. Journal of 20-a Mizhnarodna naukovo-tekhnichna konferentsiia studentiv ta aspirantiv 'Drukarstvo molode', 53-56. Retrieved from http://dm-conf.vpi.kpi.ua/2020/paper/view/19727 [in Ukrainian].

12. Agarwal, D. \& Chen, B.-C. \& Elango, P. \& Motgi, N. \& Park, S.-T. \& Ramakrishnan, R. \& Roy, S. \& Zachariah, J. (2007). Online Models for Content Optimization. Advances in Neural Information Processing Systems 21. Retrieved from https://dl.acm.org/doi/10.1145/2851581.2892359 [in English].

13. Gozhyj, A. \& Chyrun, L. \& Kowalska-Styczen, A. \& Lozynska, O. (2018). Uniform Method of Operative Content Management in Web Systems. Journal of COLINS, 62-77. Retrieved from https://ceur-ws.org/Vol-2136/10000062.pdf [in English].

14. Lytvyn, V. \& Dosyn, D. \& Emmerich, M. \& Yevseyeva, I. (2018). Content Formation Method in the Web Systems. Journal of COLINS, 42-61. Retrieved from https://ceur-ws.org/Vol-2136/10000042.pdf [in English].

15. Vorobei, V. (2019). Suchasni tekhnolohii stvorennia animatsii dlia elektronnykh vydan u formati epub [Modern Technologies for Creation of Animation for Electronic Editions in the Format of EPUB]. Journal of 19-a Mizhnarodna naukovo-tekhnichna konferentsiia studentiv ta aspirantiv 'Drukarstvo molode', 78-81. Retrieved from http://dm-conf.vpi.kpi.ua/2019/paper/view/15722 [in Ukrainian].

16. Illiashenko, N. S. \& Savchenko, O. S. (2012). SEO-optymizatsiia yak suchasnyi instrument internet-marketynhu [SEO-Optimization as a Modern Internet Marketing Tool]. Journal of Marketynh i menedzhment innovatsii, 3, 63-74 [in Ukrainian].

17. Kokarieva, K. \& Rozum, T. (2019). Suchasni tendentsii u pobudovi struktury interfeisu multymediinoho produktu [Current Trends in the Construction of the Interface of the Multimedia Product]. Journal of Suchasne reprodukuvannia: inzhynirynh, modeliuvannia, multy- ta krosmediini tekhnolohii, 66-71. Retrieved from http://ela.kpi.ua/bitstream/123456789/32030/1/Kokareva Rozum 66-71.pdf [in Ukrainian]. 
This work presents the modern technologies for preparing content for web resources and videos. Promising directions for the development of technologies for creating electronic multimedia publications are considered on the example of websites and video content with animation effects.

Keywords: testing algorithms; animation effects; animation; web design; web resource; electronic publications; web content; multimedia; patent search; preparation of content; SEO, promo video; technological processes.

\author{
Рецензент - О. І. Хмілярчук, канд. техн. наук, \\ доц., КПІ ім. Ігоря Сікорського
}

Надійшла до редакції 12.09.20 